\title{
Brain antioxidant markers, cognitive performance and acetylcholinesterase activity of rats: efficiency of Sonchus asper
}

\author{
Rahmat Ali Khan ${ }^{1,2^{*}}$, Muhammad Rashid Khan ${ }^{2}$ and Sumaira Sahreen ${ }^{2}$
}

\begin{abstract}
Background: Sonchus asper (SA) is traditionally used as a folk medicine to treat mental disorders in Pakistan. The aim of this study was to investigate the effect of polyphenolic rich methanolic fraction of SA on cognitive performance, brain antioxidant activities and acetylcholinesterase activity in male rats.

Methods: 30 male Sprague-Dawley rats were equally divided into three groups in this study. Animals of group I (control) received saline (vehicle), group II received SA (50 mg/kg) body weight (b.w.), and group III treated with SA (100 mg/kg b.w.) orally in dimethyl sulphoxide (DMSO) for 7 days. The effect of SA was checked on rat cognitive performance, brain antioxidatant and acetylcholinesterase activities. Evaluation of learning and memory was assessed by a step-through a passive avoidance test on day 6 after two habituation trials and an initial acquisition trial on day 5 . Antioxidant potential was determined by measuring activities of superoxide dismutase (SOD), catalase (CAT), contents of thiobarbituric acid reactive substances (TBARS) and reduced glutathione (GSH) in whole-brain homogenates. Acetylcholinesterase (AChE) activity was determined by the colorimetric method.
\end{abstract}

Results: Results showed that $100 \mathrm{mg} / \mathrm{kg}$ b.w., SA treated rats exhibited a significant improvement in learning and memory (step-through latency time). SA administration reduced lipid peroxidation products and elevated glutathione levels in the SA100-treated group. Furthermore, salt and detergent soluble AChE activity was significantly decreased in both SA-treated groups. Short-term orally supplementation of SA showed significant cognitive enhancement as well as elevated brain antioxidant enzymes and inhibited AChE activity.

Conclusion: These findings stress the critical impact of Sonchus asper bioactive components on brain function.

Keywords: Sonchus asper, Cognitive performance, Acetylcholinesterase activity, Antioxidant enzymes

\section{Background}

Alzheimer's disease (AD) is a slowly progressive disease of the brain that is characterized by the impairment of memory and eventually by disturbances in reasoning, planning, language, and perception. Amyloid $\beta$-peptide $(\mathrm{A} \beta)$ has been identified as a possible source of oxidative stress in $\mathrm{AD}$ because it can acquire a free-radical state that contributes to its toxic effects. A $\beta$-induced cytotoxicity is caused by intracellular accumulation of reactive

\footnotetext{
*Correspondence: rahmatgul_81@yahoo.com

'Department of Biotechnology, Faculty of Biological Sciences, University of Science and Technology Bannu, Bannu, Pakistan

${ }^{2}$ Department of Biochemistry, Faculty of Biological Sciences, Quaid-i-Azam

University Islamabad, Islamabad, Pakistan

Full list of author information is available at the end of the article
}

oxygen species, which leads to lipid peroxidation and cell death [1]. Although the precise mechanisms by which $A \beta$ induces neurotoxicity is still unknown, modulation of $A \beta$ insult has been speculated to be an important preventive and neuro protective approach to control the onset of $\mathrm{AD}$ [2]. Use of antioxidants has been recognized as an effective method in minimizing pathological and toxic effects associated with $A \beta$-induced oxidative stress. Medicinal plants play a crucial role in the treatment of AD. Ginkgo biloba L. [3], Huperzia serrata (Thunb. Ex Murray) Trevis. [4] and salvianolic acid B [5] has been extensively investigated as natural therapeutic agents for the treatment of AD patients. Previous results revealed that memory dysfunction and cognitive deficits were significantly controlled with nutrient supplementation [6,7]. 
Supplementation of Sonchus asper revealed inhibition of inflammatory mediator and nitric oxide (NO) as well as lipid peroxidation in rats [8]. The central cholinergic system is essential for the regulation of cognitive functions, as evidenced by the extensive loss of cholinergic neurons observed in the forebrain of Alzheimer's patients. Many anticholinergic drugs such as scopolamine cause learning and memory deficits in a variety of cognitive animal models [9,10]. Agonists of cholinergic receptors and inhibitors of AChE have been extensively used in order to increase endogenous acetylcholine levels and thus overcome cognitive deficits. Acetylcholinesterase metabolizes acetylcholine to choline and acetyl-CoA, which exist into asymmetric forms and globular $(G)$ forms. The G1 form is cytosolic and G4 form is membrane bound by hydrophobic amino acid sequences or glycophospholipids. The detergent soluble (DS) and salt soluble (SS) fraction of AChE contains predominantly G4 and G1 forms [11].

Fruits, vegetables and medicinal plant bioactive metabolites play a key role in the slowing of many pathogenesis and neurodegenerative disorders such as Alzheimer and dementia [12,13]. Daily consumption of fresh vegetable reported in delaying of cognitive decline in older age [14]. Beneficial effects of these metabolites are proposed to associate with potentiating of antioxidant defenses, which is linked to normal aging and neurodegenerative diseases [15]. Sonchus asper (SA) has been traditionally used in the treatment of wound [12], oxidative dysfunction, bronchitis and asthma [13], central nervous system dysfunction, mental disorders [11], might be due to the presence of phenolic compounds, ascorbic acid and carotenoids [14,15]. Phenolic compounds have anticholinesterase activities, which might be valuable for the treatment of $\mathrm{AD}$ [16]. Due to the presence of phenolic compounds in SA, the present study was arranged to investigate the effect of SA on cognitive performance, antioxidant activities of brain homogenate, TBARS, GSH content and AChE activity.

\section{Materials and methods Plant material}

Aerial parts (leaves, stem, flowers and seeds) of SA were collected and their specimen was submitted at Herbarium of Pakistan (Quaid-i-Azam University Islamabad, Pakistan). They were shade dried at room temperature, chopped and ground mechanically to a mesh size of $1 \mathrm{~mm}$.

\section{Preparation of plant extracts}

One $\mathrm{kg}$ dried sample of SA was extracted twice with 41 of absolute methanol at $25^{\circ} \mathrm{C}$. The extracts were filtrated through Whatman No. 1 fiter paper and concentrated using a rotary evaporator (Panchun Scientific Co.,
Kaohsiung, Taiwan) under reduced pressure at $40^{\circ} \mathrm{C}$. The dried extract was stored at $4^{\circ} \mathrm{C}$ for in-vivo investigations.

\section{In-vitro acetylcholinesterase inhibition assay}

The assay for AChE activity was conducted using the method of Ellman et al. [17], having acetylthiocholine iodide (ATCI) as a substrate. The rate of production of thiocholine is determined by the continuous reaction of the thiol with 5,5-dithiobis-2-nitrobenzoate (DTNB) ion to produce the yellow anion of 5-thio-2- nitro-benzoic acid. Briefly, in the 96well plates, $25 \mu \mathrm{l}$ of $15 \mathrm{mM}$ ATCI, $75 \mu \mathrm{l}$ of $3 \mathrm{mM}$ DTNB and $50 \mu \mathrm{l}$ of $50 \mathrm{mM}$ Tris $\mathrm{HCl}, \mathrm{pH}$ 8.0 , containing $0.1 \%$ bovine serum albumin (BSA), and $25 \mu \mathrm{l}$ of SA $(5-150 \mu \mathrm{g} / \mathrm{ml})$ was added and the absorbance was measured at $405 \mathrm{~nm}$ after $5 \mathrm{~min}$ of incubation at room temperature. After $25 \mu \mathrm{l}$ of $0.22 \mathrm{U} / \mathrm{ml}$ of AChE from electric eel (Sigma-Aldrich Corporation, St. Louis, MO, USA) was added, the absorbance was measured again after $5 \mathrm{~min}$ of incubation at room temperature. Percentage of inhibition was calculated by comparing the rate of enzymatic hydrolysis of ATCI for the samples to that of the blank (50\% aqueous methanol in the buffer). Galanthamine $(1-32 \mu \mathrm{M})$ was used as a reference standard and was supplied by Sigma-Aldrich. All determinations were carried out at least five times, and in triplicate, at each concentration of the standard and samples.

\section{Animals}

30 Male, albino rats (180-190 g, b.w.), were provided by National Institute of Health Islamabad and were kept in ordinary cages at room temperature of $25 \pm 3^{\circ} \mathrm{C}$ with a $12 \mathrm{~h}$ dark/light cycle. They were allowed free access to food in form of dry pellets and water and randomly divided into three groups: a vehicle group $(n=10)$ (Control), SA-treated group $(n=10)$ with SA $50 \mathrm{mg} / \mathrm{kg}$ b.w. (SA 50) and SA-treated group $(n=10)$ with $100 \mathrm{mg} \mathrm{SA} /$ kg b.w., (SA100). The SA extract was administered orally daily to SA50 and SA100 groups at a final volume $200 \mu \mathrm{l}$, while rats in the $\mathrm{C}$ group received $200 \mu \mathrm{l}$ of saline. The study protocol was approved by Ethical Committee of Quaid-I-Azam University Islamabad for laboratory animal feed and care.

\subsection{Behavioral testing: step-through a passive avoidance task}

Rats were subjected to a step-through test on day 6 , after a double training and an initial acquisition trial on day 5 . It was performed according to previously described procedures, using a two-compartment passive avoidance apparatus (white/dark, separated by a black wall with a guillotine door in the middle part), with minor modifications of the time intervals. In detail, on day 5, the animals were allowed to habituate in the experimental room 
for $1 \mathrm{~h}$ prior to experiments. One hour later, each rat was placed in the illuminated chamber for the acquisition trial and was left to habituate to the apparatus. One hundred seconds later, the guillotine door was opened, and the animal was allowed to enter the dark compartment. The latency with which the animal crossed into the dark compartment was recorded. Animals that waited more than $100 \mathrm{~s}$ to enter the dark compartment were eliminated from the experiments. Once the animal crossed with all four paws to the next compartment, the guillotine door was closed, and the rat was taken into its home cage. The trial was repeated after $30 \mathrm{~min}$ as in the acquisition trial, where after $5 \mathrm{~s}$ the guillotine door was opened and as soon as the animal crossed to the dark compartment the door was closed and a foot shock $(25 \mathrm{~V}, 3 \mathrm{~mA}, 5 \mathrm{~s})$ was immediately delivered to the grid floor of the dark room. Thereafter, the rat was immediately removed from the apparatus and returned to its home cage. In this trial, the initial latency (IL) of entrance into the dark chamber was recorded (maximum time allowed was $120 \mathrm{~s}$ ). Twenty-four hours after training, a retention test was performed to determine longterm memory. Each animal was placed in the light compartment for $20 \mathrm{~s}$. The door was opened, and the stepthrough latency (STL) was measured for entering into the dark compartment. The test session ended when the animal entered the dark compartment or remained in the light compartment for $300 \mathrm{~s}$ (criterion for retrieval). During these sessions, no electric shock was applied. All training and testing sessions were carried out during the light phase between 08:00 and 14:00 h.

\section{Ex vivo assessment of antioxidant enzymes}

After completions of experiment rats were killed, and whole intact brain was carefully removed and incubated on an ice chilled for cleaning. The cerebellum was separated immediately while rest of brain tissue was homogenized in a phosphate buffer $(\mathrm{pH} 7.6)$, centrifuged at $20,000 \times g, 4 \rrbracket C$ for $2 \mathrm{~h}$ to obtain a soluble salt part (SS). Re-extraction of the pellets was carried out to get a soluble detergent part (DS) [18]. The supernatant was collected and stored at $-20 \otimes C$. Protein concentrations were determined by the Bradford assay with Bovine serum albumin as standard $(0.05-1.00 \mathrm{mg} / \mathrm{ml})$.

\section{AChE assessment}

AChE activity was determined using the colorimetric assay of Ellman et al. [17], as previously described. Briefly, in the 96 well plates, $25 \mu \mathrm{l}$ of $15 \mathrm{mM}$ ATCI, $75 \mu \mathrm{l}$ of $3 \mathrm{mM}$ DTNB and $75 \mu \mathrm{l}$ of $50 \mathrm{mM}$ Tris- $\mathrm{HCl}, \mathrm{pH} 8.0$, containing $0.1 \% \mathrm{BSA}$, were added and the absorbance was read at $405 \mathrm{~nm}$ after five min incubation at room temperature. Any increase in absorbance due to the spontaneous hydrolysis of the substrate was corrected by subtracting the rate of the reaction before adding the enzyme. Then, $25 \mu \mathrm{l}$ of sample (SS and DS fraction of brain homogenates) was added, and the absorbance was read again after $5 \mathrm{~min}$ of incubation at room temperature. The AChE activity is expressed as $\mathrm{mol} / \mathrm{min} / \mathrm{g}$ of tissue protein. All determinations were carried out twice and in triplicate.

\section{Catalase assay (CAT)}

CAT activities were determined with reaction solution contained: $2.5 \mathrm{ml}$ of $50 \mathrm{mmol}$ phosphate buffers

( $\mathrm{pH} 5.0$ ), $0.4 \mathrm{ml}$ of $5.9 \mathrm{mmol} \mathrm{H}_{2} \mathrm{O}_{2}$ and $0.1 \mathrm{ml}$ tissue homogenate. Changes in absorbance of the reaction solution at $240 \mathrm{~nm}$ were determined after one minute. One unit of catalase activity was defined as an absorbance change of 0.01 as units/min [19].

\section{Superoxide dismutase assay (SOD)}

SOD activity was estimated by the method of Kakar et al. [20]. Reaction mixture of this method contained: $0.1 \mathrm{ml}$ of phenazine methosulphate $(186 \mu \mathrm{mol}), 1.2 \mathrm{ml}$ of sodium pyrophosphate buffer (0.052 mmol; pH 7.0), $0.3 \mathrm{ml}$ of the supernatant after centrifugation $(1500 \times \mathrm{g}$ for $10 \mathrm{~min}$ followed by $10,000 \times \mathrm{g}$ for $15 \mathrm{~min}$ ) of homogenate was added to the reaction mixture. Enzyme reaction was initiated by adding $0.2 \mathrm{ml}$ of NADH $(780 \mu \mathrm{mol})$ and stopped after $1 \mathrm{~min}$ by adding $1 \mathrm{ml}$ of glacial acetic acid. Amount of chromogen formed was measured by recording color intensity at $560 \mathrm{~nm}$. Results are expressed in units/mg protein.

\section{Glutathione-S-transferase assay (GST)}

The glutathione-S-transferase activity mixture consisted of $1.475 \mathrm{ml}$ phosphate buffer $(0.1 \mathrm{~mol}, \mathrm{pH} 6.5), 0.2 \mathrm{ml}$ reduced glutathione (1 mmol), $0.025 \mathrm{ml} \mathrm{1-Chloro-2,4-}$ dinitrobenzene (CDNB) (1 mmol) and $0.3 \mathrm{ml}$ of homogenate in a total volume of $2.0 \mathrm{ml}$. The changes in the absorbance were recorded at $340 \mathrm{~nm}$ and enzymes activity was calculated as nmol CDNB conjugate formed/ $\mathrm{min} / \mathrm{mg}$ protein using a molar extinction coefficient of $9.6 \times 10^{3} \mathrm{M}^{-1} \mathrm{~cm}^{-1}[21]$.

\section{Glutathione reductase assay (GSR)}

Glutathione reductase activity was determined by method of Carlberg and Mannervik [22]. The reaction mixture consisted of $1.65 \mathrm{ml}$ phosphate buffer: (0.1 mol; $\mathrm{pH} 7.6), 0.1 \mathrm{ml}$ ethylenediaminetetraacetic acid (EDTA) (0.5 mmol), $0.05 \mathrm{ml}$ oxidized glutathione (1 mmol), $0.1 \mathrm{ml}$ nicotinamide adenine dinucleotide phosphate (NADPH) $(0.1 \mathrm{mmol})$ and $0.1 \mathrm{ml}$ of homogenate in a total volume of $2 \mathrm{ml}$. Enzyme activity were quantitated at $25^{\circ} \mathrm{C}$ by measuring disappearance of $\mathrm{NADPH}$ at $340 \mathrm{~nm}$ and was calculated as nmol NADPH oxidized/ 
$\mathrm{min} / \mathrm{mg}$ protein using a molar extinction coefficient of $6.22 \times 10^{3} \mathrm{M}^{-1} \mathrm{~cm}^{-1}$.

\section{Glutathione peroxidase assay (GSH-Px)}

Glutathione peroxidase activity was assayed by the method of Mohandas et al. [23] (1984). The reaction mixture consisted of $1.49 \mathrm{ml}$ phosphate buffer $(0.1 \mathrm{~mol}$; pH 7.4), $0.1 \mathrm{ml}$ EDTA (1 mmol), $0.1 \mathrm{ml}$ sodium azide (1 $\mathrm{mmol}), 0.05 \mathrm{ml}$ glutathione reductase $(1 \mathrm{IU} / \mathrm{ml})$, $0.05 \mathrm{ml} \mathrm{GSH}$ (1 mmol), $0.1 \mathrm{ml} \mathrm{NADPH}(0.2 \mathrm{mmol})$, $0.01 \mathrm{ml} \mathrm{H}_{2} \mathrm{O}_{2}(0.25 \mathrm{mmol})$ and $0.1 \mathrm{ml}$ of homogenate in a total volume of $2 \mathrm{ml}$. The disappearance of NADPH at $340 \mathrm{~nm}$ was recorded at $25^{\circ} \mathrm{C}$. Enzyme activity was calculated as nmol NADPH oxidized $/ \mathrm{min} / \mathrm{mg}$ protein using a molar extinction coefficient of $6.22 \times 10^{3} \mathrm{M}^{-1} \mathrm{~cm}^{-1}$.

\section{Reduced glutathione assay (GSH)}

Reduced glutathione was estimated by the method of Jollow et al. [24], using DTNB as a substrate. The yellow color developed was read immediately at $412 \mathrm{~nm}$ and expressed as $\mu \mathrm{mol} \mathrm{GSH} / \mathrm{g}$ tissue.

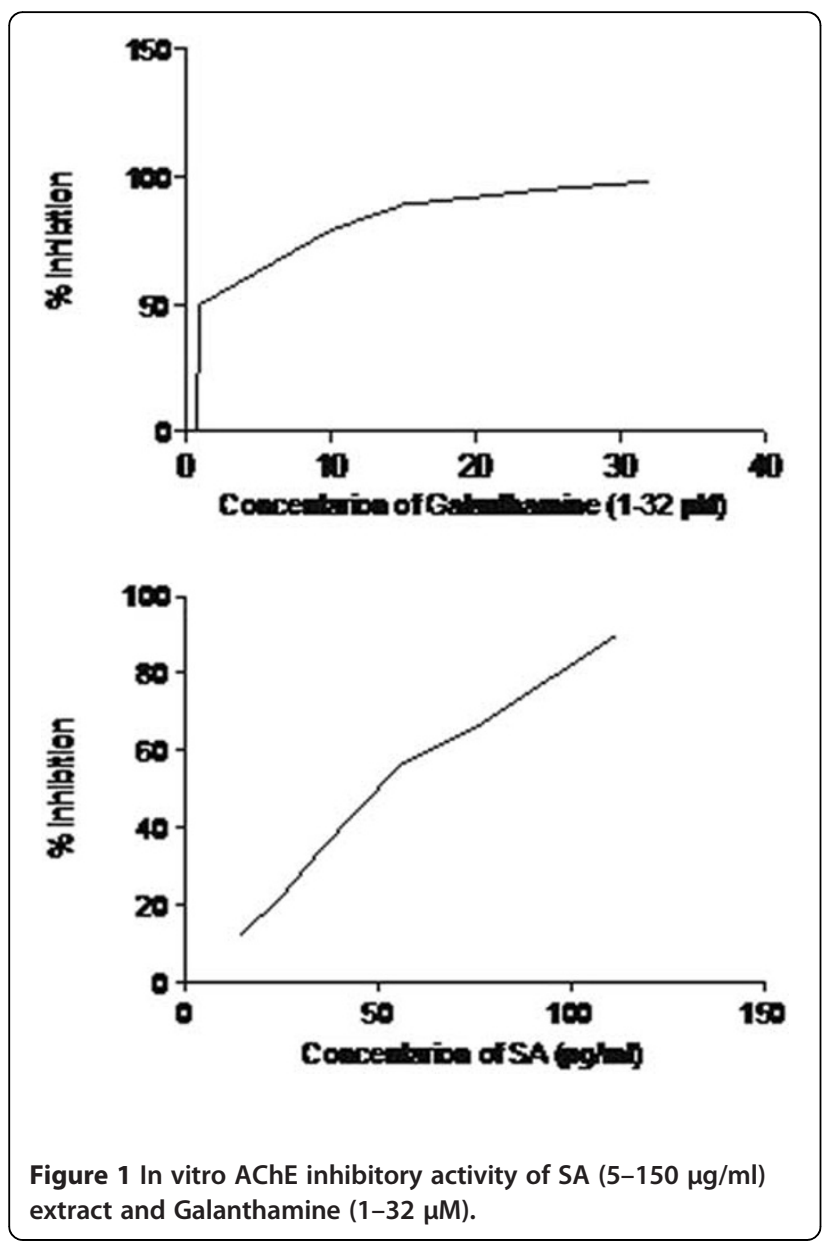

Table 1 Showing IL and STL

\begin{tabular}{lcc}
\hline Treatment & IL & STL \\
\hline Control & $28 \pm 3$ & $101 \pm 32$ \\
\hline SA50 & $24 \pm 3$ & $108 \pm 50$ \\
\hline SA100 & $28 \pm 7$ & $218 \pm 50^{*}$
\end{tabular}

The effect of orally administration of 50 and $100 \mathrm{mg} \mathrm{SA} \mathrm{extract/kg} \mathrm{BW}$ on initial latency (IL) and step-through latency (STL) in the double trial stepthrough test. Asterisk $\left(^{*}\right)$ indicates significant difference from the control littermates ( $n=10 /$ group)

\section{Estimation of a lipid peroxidation assay (TBARS)}

The assay for lipid peroxidation was carried out following the modified method of Iqbal et al. [25]. The reaction mixture in a total volume of $1.0 \mathrm{ml}$ contained $0.58 \mathrm{ml}$ phosphate buffer (0.1 mol; pH 7.4), $0.2 \mathrm{ml}$ homogenate sample, $0.2 \mathrm{ml}$ ascorbic acid $(100 \mathrm{mmol})$, and $0.02 \mathrm{ml}$ ferric chloride $(100 \mathrm{mmol})$. The reaction mixture was incubated at $37^{\circ} \mathrm{C}$ in a shaking water bath for $1 \mathrm{~h}$. The reaction was stopped by addition of $1.0 \mathrm{ml} 10 \%$ trichloroacetic acid. Following addition of $1.0 \mathrm{ml} 0.67 \%$ thiobarbituric acid, all the tubes were placed in boilingwater bath for $20 \mathrm{~min}$ and then shifted to crushed icebath before centrifuging at $2500 \times \mathrm{g}$ for $10 \mathrm{~min}$. The amount of TBARS formed in each of the samples was assessed by measuring optical density of the supernatant at $535 \mathrm{~nm}$ using a spectrophotometer against a reagent blank. The results were expressed as nmol TBARS/min/ mg tissue at $37^{\circ} \mathrm{C}$ using a molar extinction coefficient of $1.56 \times 10^{5} \mathrm{M}^{-1} \mathrm{~cm}^{-1}$.

\section{Statistical analysis}

Data were expressed as standard error mean (Mean \pm SEM) and one-way analysis of variance (ANOVA). The least significant difference (LSD) was determined using post hoc testing for inter group comparisons at a probability level of $0.05 \%$ and $0.01 \%$. SPSS ver 14.0 (Chicago, IL, USA) and Microsoft Excel 2003 (Roselle, IL, USA) were used for the statistical and graphical evaluations.

\section{Results}

In vitro analysis of SA on AChE activity

In order to check the direct inhibition of AChE, SA and galanthamine are used. Acetylcholinesterase degrades the neurotransmitter acetylcholine, producing choline and an acetate group. Figure 1 presents that SA exhibited

Table 2 Showing body weight before and after treatment and wet brain weight

\begin{tabular}{lccc}
\hline Treatment & Control & SA50 & SA100 \\
\hline Body weight before treatment $(\mathrm{g})$ & $186.2 \pm 3.4$ & $183.6 \pm 4.2$ & $188.2 \pm 7.9$ \\
Body weight after treatment $(\mathrm{g})$ & $200.0 \pm 5.4$ & $189.5 \pm 3.8$ & $195.8 \pm 7.2$ \\
Wet brain weight $(\mathrm{mg})$ & $362.2 \pm 3.5$ & $361.5 \pm 5.1$ & $357.1 \pm 3.4$ \\
\hline Mean \pm S.E.M values ( $n=10$ /group) & & &
\end{tabular}


Table 3 Effect of orally Sonchus asper (SA) administration for 7 days on ex vivo acetylcholinesterase (AChE) activity ( $\mathrm{mol} / \mathrm{min} / \mathrm{g}$ of tissue protein) in rat brain

\begin{tabular}{lcc}
\hline Treatment & Salt soluble (SS)-AChE & Detergent soluble (DS)-AChE \\
\hline Control & $0.175 \pm 0.0057$ & $0.889 \pm 0.074$ \\
SA50 & $0.101 \pm 0.002^{*}$ & $0.525 \pm 0.031^{* *}$ \\
SA100 & $0.074 \pm 0.010^{* *}$ & $0.300 \pm 0.051^{* *}$
\end{tabular}

* $p<0.05$ significant difference from control

${ }^{* *} p<0.01$ significant difference from control

The AChE activity for each group denotes mean \pm S.E.M values

moderate AChE inhibitory activity with an IC50 $65 \mu \mathrm{g} /$ $\mathrm{ml}$ while galanthamine an alkaloid extracted from Galanthus nivalis with an IC50 $1.17 \mu \mathrm{M}$.

\section{Effect of SA extracts on the behavioral study}

The changes of SA extract injected orally to rats for six days on the step-through learning capability is shown in Table 1. These changes are shown as the mean(s) of IL and STL for rats of each group. The STL involves relative resistant stimuli and is a direct measure of passive avoidance behavior. In the control, SA50 and SA100 groups, the IL was not significantly different $(28 \pm 3,24$ \pm 3 and $28 \pm 10 \mathrm{~s}$ ), indicating that all groups behaved the same in the training trial. However, the SA100 group exhibited a significant increase $(p>0.05)$ in STL to 218 $\pm 50 \mathrm{~s}, 1$ day after the acquisition trial, as compared to the control group (101 $\pm 32 \mathrm{~s})$. No significant difference was observed in the SA50 group in comparison to the control group. Apparently, the SA extracts of $100 \mathrm{mg} / \mathrm{kg}$ b.w. facilitated learning in comparison to the control group, as is evident by the delay of transfer in the dark chamber.

\section{Animal body and brain weight}

No significant changes were observed in body weight of treated and control rats before, and after the administration of the SA extracts for seven days. Similarly, no considerable differences in the wet weight of the whole brain between control and SA treated rats (Table 2).
The ex vivo effect of SA extracts on brain AChE activity In order to determine $\mathrm{AChE}$ levels in the brain of rats, the soluble salt part (SS) and detergent soluble part (DS) fractions of brain homogenates were assayed using the colorimetric method of Ellman et al. [17] (Table 3). Short-term SA administration (SA50 and SA100) resulted in a significant decrease in AChE specific activity in both SS and DS fractions as compared to control.

\section{Effect of SA extracts on brain oxidative status}

Table 4 shows changes in brain activities of antioxidant enzymes, glutathione and TBARS contents in all the experimental groups of rat. Administration of SA significantly $(p<0.05)$ altered the concentration of SOD, CAT and TBARS in a dose-dependent way. In particular, SA administration at $100 \mathrm{mg} / \mathrm{kg}$ b.w. almost reduced the concentration of TBARS in brain tissue. Additionally, the levels of GSH and activities of GST, GSR and GSHpx were significantly $(p<0.05)$ increased in the brain tissue of SA50 and SA100-treated rats.

\section{Discussion}

The present study has been carried out using rats for investigation of learning task. The passive avoidance task is a fear-aggravated test used to evaluate learning and memory in rodent models of CNS disorders. In this test, subjects learn to avoid an environment in which an aversive stimulus (such as a foot-shock) was delivered. On $5^{\text {th }}$ day the IL to enter the dark chamber is measured as a control for visual ability and motor activity. In our experiment, the mean IL values did not differ among the different groups. The STL is a measure of the memory of the aversive experience. The mean STL of rat treated with the high concentration of the SA extract (SA100) was significantly higher than those of the other groups on day 6. These results are in agreement with recent reports on the long-term memory enhancing effect in the inhibition avoidance test of dietary supplementation with Vaccinium ashei (Ericaceae) (rabbiteye blueberries) of 3-month-old mice for 30 days [26]. Data of the present study revealed that Sonchus asper significantly

Table 4 Effect of orally SA administration for 7 days in biochemical parameters of rat brain antioxidant status

\begin{tabular}{|c|c|c|c|c|c|c|c|}
\hline Treatment & $\begin{array}{l}\text { Catalase } \\
\text { (U/min) }\end{array}$ & $\begin{array}{l}\text { Superoxide } \\
\text { dismutase } \\
\text { (U/mg protein) }\end{array}$ & $\begin{array}{l}\text { Glutathione } \\
\text { peroxidase assay } \\
\text { (nmol/mg protein) }\end{array}$ & $\begin{array}{l}\text { Glutathione } \\
\text { reductase } \\
\text { (nmol/min/mg } \\
\text { protein) }\end{array}$ & $\begin{array}{l}\text { Glutathione-S-transferase } \\
\text { (nmol/min/mg protein) }\end{array}$ & $\begin{array}{l}\text { Reduced } \\
\text { glutathione } \\
\text { ( } \mu \mathrm{mol} / \mathrm{g} \text { tissue) }\end{array}$ & $\begin{array}{l}\text { Thiobarbituric } \\
\text { acid reactive } \\
\text { substances } \\
\text { (nmol/min/ } \\
\text { mg protein) }\end{array}$ \\
\hline Control & $11.0 \pm 0.25$ & $7.18 \pm 2.8$ & $43.3 \pm 3.58$ & $174.5 \pm 20.7$ & $115.8 \pm 26.11$ & $64.5 \pm 10.7$ & $184.5 \pm 8.7$ \\
\hline SA50 & $15.5 \pm 2.8^{*}$ & $13.5 \pm 1.4^{* *}$ & $55.3 \pm 1.85^{*}$ & $203.3 \pm 10.3^{* *}$ & $139.8 \pm 13.3$ * & $88.0 \pm 8.3^{*}$ & $200.3 \pm 7.3^{*}$ \\
\hline SA100 & $14.0 \pm 1.12^{*}$ & $18.3 \pm 1.7^{* *}$ & $65.3 \pm 5.14^{* *}$ & $218.0 \pm 10.5 * *$ & $150.8 \pm 11.5^{* *}$ & $91.8 \pm 10.0^{* *}$ & $208.0 \pm 10.0^{* *}$ \\
\hline
\end{tabular}

${ }^{*} p<0.05$ significant difference from control littermates ( $n=10 /$ group)

${ }^{* *} p<0.01$ significant difference from control littermates ( $n=10 /$ group)

The rats brain biochemical parameters are expressed as mean \pm S.E.M values 
decreased brain AChE activity in rats. This result supports the ideas, which might be due to a decrease in gene transcription, translation and enhance cholinergic activity thereby improving cognitive function [27]. AChE activity was decreased in both SS and DS fractions, with significant effects in rats treated with SA 100 comparatively SA50 rats treated group. Oxidative stress and antioxidant system play an important role in pathophysiological cerebral changes. Evaluation of the protective effect Sonchus asper on rat brain oxidative stress parameters and antioxidant mechanisms was an important aim of our study. The activity of SOD is a sensitive index in oxidative damage as it scavenges the superoxide anion to form hydrogen peroxide leading to diminish the toxic effects. The catalase is enzymatic antioxidants, widely distributed in all animal tissues that decompose hydrogen peroxide and protect the tissue from highly reactive hydroxyl radicals. Data revealed that administration of both SA50 and SA100 increased the activity of SOD and CAT as reported during supplementation Sonchus asper in rat [8].

Glutathione reduced, glutathione reductase and glutathione-S-transferase is thought to be the fundamental antioxidant enzymes, for they are closely related to the direct elimination of reactive oxygen species. Therefore, the reduction in the activity of these enzymes may result in a number of deleterious effects due to the accumulation of superoxide radicals and hydrogen peroxide, linked with neurodegenerative diseases [28]. Supplementation of SA100 and SA50 for seven days improved the activity, showing protection against free radicals. From these results, it was inferred that administration of SA in healthy rat attenuated brain oxidative damages, increased activity of antioxidant enzymes, GSH and AChE while decreased TBARS level. These antioxidant effects of SA were might be associated with the enhancement in performance in the passive avoidance behavioral test. Although the mechanisms underlying these effects are still unknown and require more pharmacological, neurochemical and pharmacokinetic research to establish any therapeutic advantage. However excessive use of SA is could be suggested for the prevention of cognitive decline during aging and neurodegenerative disease.

\section{Competing interests}

The authors declare that they have no competing interests.

\section{Authors' contributions \\ RAK made a significant contribution to acquisition of and analyses of data and drafting of the manuscript. MRK made a substantial contribution to the conception and design of the study, interpretation of data, as well as drafting and revising of the manuscript. SS participated in the study design as well as the collection and analyses of data. All authors read and approved the final manuscript.}

\section{Author details}

${ }^{1}$ Department of Biotechnology, Faculty of Biological Sciences, University of Science and Technology Bannu, Bannu, Pakistan. ${ }^{2}$ Department of
Biochemistry, Faculty of Biological Sciences, Quaid-i-Azam University Islamabad, Islamabad, Pakistan.

Received: 13 October 2011 Accepted: 27 April 2012

Published: 16 May 2012

\section{References}

1. Kumar U, Dunlop DM, Richardson JS: The acute neurotoxic effect of $\beta$-amyloid on mature cultures of rat hippocampal neurons is attenuated by the anti-oxidant U-78517 F. Int/ J neurosci 1994, 1994(79):185-190.

2. Kim DSHL, Park SY, Kim JK: Curcuminoids from Curcuma longa L. (Zingiberaceae) that protect $\mathrm{PC} 12$ rat pheochromocytoma and normal human umbilical vein endothelial cells from $\beta A(1-42)$ insult. Neurosci Letters 2001, 303:57-61.

3. Oken BS, Storzbach DM, Kaye JA: The efficacy of Ginkgo biloba on cognitive function in Alzheimer disease. Arch Neurol 1995, 55:1409-14015.

4. Skolnick AA: Old Chinese herbal medicine used for fever yields possible new Alzheimer disease therapy. J Am Med Assoc 1997, 277:776.

5. Durairajan SS, Yuan Q, Xie L, Chan WS, Kum WF, Koo I, Liu C, Song Y, Huang JD, Klein WL, Li M: Salvianolic acid B inhibits $A \beta$ fibril formation and disaggregates preformed fibrils and protects against $A \beta$-induced cytotoxicty. Neurochem Int/ 2008, 52:741-750.

6. Joseph JA, Shukitt-Hale B, Denisova NA, Bielinski D, Martin A, McEwen JJ: Reversals of age-related declines in neuronal signal transduction, cognitive, and motor behavioural deficits with blueberry, spinach, or strawberry dietary supplementation. J Neurosci 1999, 19:8114-8121.

7. Shukitt-Hale B, Lau FC, Joseph JA: Berry fruit supplementation and the aging brain. J Agric Food Chem 2008, 56:636-641.

8. Khan RA, Khan MR, Sahreen S, Bokhari J: Prevention of $\mathrm{CCl}_{4}$-induced nephrotoxicity with Sonchus asper in rat. Food Chem Toxicol 2010, 48:2469-2476

9. Sarter M, Bruno JP: Cognitive functions of cortical acetylcholine: toward a unifying hypothesis. Brain Res Rev 1997, 23:28-46.

10. Zimmerman G, Soreq H: Termination and beyond: acetylcholinesterase as a modulator of synaptic transmission. Cell Tissue Res 2006, 326:655-669.

11. Lane RM, Potkin SG, Enz A: Targeting acetylcholinesterase and butyrylcholinesterase in dementia. Intl J Neuropsycopharmacol 2006, 9:101-124.

12. Rehman EU: Indigenous knowledge on medicinal plants, village Barali Kass and its allied areas, District Kotli Azad Jammu and Kashmir, Pakistan. Ethno Leaflets 2006, 10:254-264.

13. Dai $Q$, Borenstein $A R, W u Y$, Jackson JC, Larson EB: Fruit and vegetable juices and Alzheimer's disease: the Kame Project. Am J Med 2006, 119:751-759.

14. Letenneur L, Proust-Lima C, Le Gouge A, Dartigues JF, BPrBerger-Gateau P: Flavonoid intake and cognitive decline over a 10-year period. Am J Epidemiol 2007, 165:1364-1371.

15. Morris MC, Evans DA, Tangney CC, Bienias JL, Wilson RS: Associations of vegetable and fruit consumption with age-related cognitive change. Neurology 2006, 67:1370-1376.

16. Tumiatti $\mathrm{V}$, Bolognesi ML, Minarini A, Rosini M, Milelli A, Matera R: Progress in acetylcholinesterase inhibitors for Alzheimer's disease: an update. Expert Opinion on Therapeutic Patents 2008, 12:45-56.

17. Ellman GL, Courtney KD, Andres V, Featherstone RM: A new and rapid colorimetric determination of acetylcholinesterase activity. Biochem Pharmacol 1961, 7:88-95.

18. Kameyama T, Nabeshima T, Kozawa T: Step-down-type passive avoidanceand escape-learning method. Suitability for experimental amnesia models. J Pharmacol Methods 1986, 16:39-52.

19. Chance B, Maehly AC: Assay of catalase and peroxidases. Met Enzymol 1955, 11:764-775.

20. Kakkar P, Das B, Viswanathan PN: A modified spectrophotometric assay of superoxide dismutase. Indian J Biochem Biophys 1984, 21:130-132.

21. Habig WH, Pabst MJ, Jakoby WB: Glutathione-S-transferases: the first enzymatic step in mercapturic acid formation. J Biol Chem 1974, 249:7130-7139.

22. Carlberg I, Mannervik EB: Glutathione level in rat brain. J Biol Chem 1975 , 250:4475-4480.

23. Mohandas J, Marshal JJ, Duggin GG, Horvath JS, Tiller DJ: Differential distribution of glutathione and glutathione-related enzymes in rabbit 
kidney. Possible implications in analgesic nephropathy. Biochem Pharmacol 1984, 33:1801-1807.

24. Jollow DJ, Mitchell JR, Zampaglione N, Gillete JR: Bromobenzene induced liver necrosis. Protective role of glutathione and evidence for

3, 4-bromobenzene oxide as a hepatotoxic metabolite. Pharmacol 2003, 11:151-169.

25. Iqbal M, Sharma MD, Zadeh HR, Hasan N, Abdulla M, Athar M: Glutathione metabolizing enzymes and oxidative stress in ferric nitrilotriacetate (Fe-NTA) mediated hepatic injury. Redox Report 1996, 2:385-391.

26. Sabeen M, Ahmad AA: Exploring the Folk Medicinal Flora of Abbotabad City, Pakistan. Ethno Leaflets 2009, 13:810-833.

27. Shahidi S, Komaki A, Mahmoodi M, Atrvash N, Ghodrati M: Ascorbic acid supplementation could affect passive avoidance learning and memory in rat. Brain Res Bull 2008, 76:109-113.

28. Fang $Y Z$, Yang $S$, Wu G: Free radicals, antioxidants, and nutrition. Nutrition 2000, 18:872-879.

doi:10.1186/1744-9081-8-21

Cite this article as: Khan et al:: Brain antioxidant markers, cognitive performance and acetylcholinesterase activity of rats: efficiency of Sonchus asper. Behavioral and Brain Functions 2012 8:21.

\section{Submit your next manuscript to BioMed Central and take full advantage of:}

- Convenient online submission

- Thorough peer review

- No space constraints or color figure charges

- Immediate publication on acceptance

- Inclusion in PubMed, CAS, Scopus and Google Scholar

- Research which is freely available for redistribution 